Article

\title{
In Vitro Sensitization of Erythrocytes to Programmed Cell Death Following Baicalein Treatment
}

\author{
Rosi Bissinger ${ }^{1}$, Abaid Malik ${ }^{1}$, Sabina Honisch ${ }^{1}$, Jamshed Warsi ${ }^{1}$, Kashif Jilani ${ }^{2}$ and \\ Florian Lang ${ }^{1, *}$
}

1 Department of Physiology, University of Tübingen, Gmelinstr. 5, 72076 Tuebingen, Germany; E-Mails: ro.bissinger@gmx.de (R.B.); malik.abaid@googlemail.com (A.M.); honisch.s@gmx.de (S.H.); jamshedwarsi@yahoo.com (J.W.)

2 Department of Biochemistry, University of Agriculture, 38040 Faisalabad, Pakistan; E-Mail: kashif_cbc@yahoo.com

* Author to whom correspondence should be addressed; E-Mail: florian.lang@uni-tuebingen.de; Tel.: +49-7071-29-72194; Fax: +49-7071-29-5618.

Received: 9 May 2014; in revised form: 3 September 2014 / Accepted: 4 September 2014 / Published: 18 September 2014

\begin{abstract}
The polyphenolic flavonoid Baicalein has been shown to trigger suicidal death or apoptosis of tumor cells and is thus considered for the prevention and treatment of malignancy. Similar to apoptosis of nucleated cells, erythrocytes may enter eryptosis, the suicidal erythrocyte death characterized by cell shrinkage and cell membrane scrambling with phosphatidylserine translocation to the erythrocyte surface. Stimulators of eryptosis include increase of cytosolic $\mathrm{Ca}^{2+}$-activity $\left(\left[\mathrm{Ca}^{2+}\right]_{i}\right)$ and ceramide. The present study explored whether Baicalein stimulates eryptosis. To this end, forward scatter was taken for measurement of cell volume, annexin-V-binding for phosphatidylserine-exposure, Fluo3 fluorescence for $\left[\mathrm{Ca}^{2+}\right]_{i}$ and fluorescent antibodies for ceramide abundance. As a result, a $48 \mathrm{~h}$ exposure of human erythrocytes to Baicalein was followed by significant decrease of forward scatter $(\geq 10 \mu \mathrm{M})$, significant increase of the percentage of annexin-V-binding cells $(\geq 25 \mu \mathrm{M})$, significant increase of $\left[\mathrm{Ca}^{2+}\right]_{i}(50 \mu \mathrm{M})$ and significant increase of ceramide abundance $(50 \mu \mathrm{M})$. The effect of Baicalein $(50 \mu \mathrm{M})$ on annexin-V-binding was significantly blunted but not abrogated by removal of extracellular $\mathrm{Ca}^{2+}$. In conclusion, at the concentrations employed, Baicalein stimulates suicidal erythrocyte death or eryptosis, an effect at least in part due to the combined effects of $\mathrm{Ca}^{2+}$ entry and ceramide formation.
\end{abstract}


Keywords: phosphatidylserine; Baicalein; Calcium; cell volume; ceramide; eryptosis

\section{Introduction}

Baicalein, a major polyphenolic flavonoid from dried roots of Scutellaria baicalensis [1], has been shown to protect against a wide variety of malignancies [2-8]. Baicalein is effective at least in part by triggering apoptosis [2,4,7,9-14]. On the other hand, Baicalein may protect against apoptosis [15-18]. Along those lines, Baicalein is a potent free radical scavenger and xanthine oxidase inhibitor supporting endothelial function and protecting against oxidative stress-induced cell injury [1]. Cellular mechanisms involved in the effects of Baicalein include suppression of the transcription factor NF- $\kappa \mathrm{B}[11,19,20]$, modulation of the PI3K/Akt pathway [3,12,21] and mitochondria-dependent caspase activation [9].

Similar to apoptosis of nucleated cells, erythrocytes may enter eryptosis, a suicidal erythrocyte death characterized by cell shrinkage and cell membrane scrambling with translocation of phosphatidylserine to the cell surface [22]. Eryptosis is stimulated by increase of cytosolic $\mathrm{Ca}^{2+}$ concentration $\left(\left[\mathrm{Ca}^{2+}\right]_{i}\right)$, which is followed by activation of $\mathrm{Ca}^{2+}$-sensitive $\mathrm{K}^{+}$channels with subsequent $\mathrm{K}^{+}$exit, hyperpolarization, $\mathrm{Cl}^{-}$exit and thus cellular loss of $\mathrm{KCl}$ and water with subsequent cell shrinkage [23] as well as by cell membrane scrambling with subsequent phosphatidylserine exposure at the erythrocyte surface [22]. Stimulators of eryptosis further include ceramide formation [24], caspase activation [25-29] and deranged activities of AMP activated kinase AMPK [30], casein kinase $1 \alpha$ [31,32], cGMP-dependent protein kinase [26], Janus-activated kinase JAK3 [33], protein kinase C [34], p38 kinase [35], PAK2 kinase [36], sorafenib sensitive kinases [37] and sunitinib sensitive kinases [38].

Eryptosis is elicited by a wide variety of xenobiotics [24,37-68] and is observed in several clinical conditions including sepsis, malaria, sickle cell disease, Wilson's disease, iron deficiency, malignancy, metabolic syndrome, diabetes, renal insufficiency, hemolytic uremic syndrome, hyperphosphatemia and phosphate depletion [22,69]. However, to the best of our knowledge, experiments exploring an effect of the polyphenolic flavonoid Baicalein on eryptosis have never been reported.

The present study thus tested whether Baicalein stimulates eryptosis. To this end, human erythrocytes were incubated in Ringer with or without presence of Baicalein and cell volume, phosphatidylserine abundance at the cell surface, $\left[\mathrm{Ca}^{2+}\right]_{i}$, as well as ceramide abundance determined utilizing flow cytometry.

\section{Results and Discussion}

The present study explored the influence of the polyphenolic flavonoid Baicalein on eryptosis, the suicidal erythrocyte death characterized by cell shrinkage and phosphatidylserine translocation to the cell surface.

In a first step, cell volume was estimated from forward scatter determined in flow cytometry following an incubation of human erythrocytes for $48 \mathrm{~h}$ in Ringer solution without or with Baicalein $(5-50 \mu \mathrm{M})$. As shown in Figure 1, Baicalein treatment was followed by a decrease of 
average erythrocyte forward scatter reflecting cell shrinkage, an effect reaching statistical significance at $10 \mu \mathrm{M}$ Baicalein concentration. The histogram reveals that Baicalein increases forward scatter in a subpopulation of erythrocytes.

Figure 1. Effect of Baicalein on erythrocyte forward scatter. (A) Original histogram of forward scatter of erythrocytes following exposure for $48 \mathrm{~h}$ to Ringer solution without (grey area) and with (black line) presence of $50 \mu \mathrm{M}$ Baicalein; (B) Arithmetic means \pm SEM $(n=12)$ of the normalized erythrocyte forward scatter (FSC) following incubation for $48 \mathrm{~h}$ to Ringer solution without (white bar) or with (black bars) Baicalein $(5-50 \mu \mathrm{M})$. $* *(p<0.01), * * *(p<0.001)$ indicate significant difference from the absence of Baicalein (ANOVA); (C) Arithmetic means $\pm \operatorname{SEM}(n=5)$ of forward scatter (arbitrary units) in erythrocytes exposed for 6-48 h to Ringer solution without (white squares) or with $50 \mu \mathrm{M}$ Baicalein (black squares). ${ }^{*}(p<0.05)$ indicates significant difference from the absence of Baicalein.
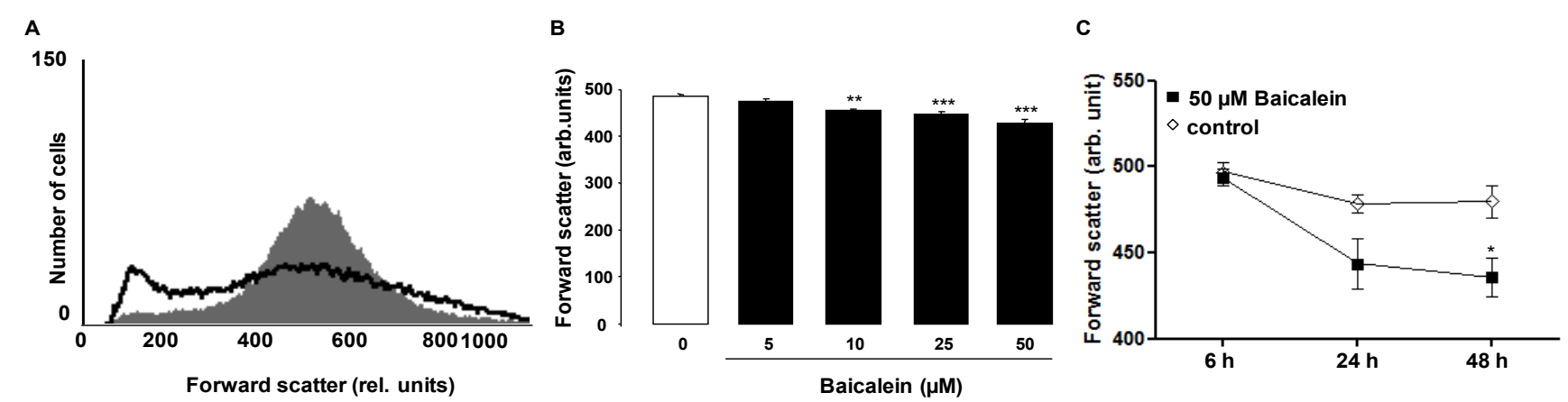

In a second step, cell membrane phospholipid scrambling with phosphatidylserine translocation to the erythrocyte surface was quantified utilizing annexin-V-binding in flow cytometry following a $48 \mathrm{~h}$ incubation in Ringer solution without or with Baicalein $(5-50 \mu \mathrm{M})$. As illustrated in Figure 2, a $48 \mathrm{~h}$ treatment with Baicalein increased the percentage of annexin-V-binding erythrocytes, an effect reaching statistical significance at $25 \mu \mathrm{M}$ Baicalein concentration.

The effect of Baicalein on phosphatidylserine exposure is paralleled by hemolysis, which, however, affects fewer erythrocytes than cell membrane scrambling (Figure 2). The phosphatidylserine exposure was not modified by inhibition of caspases with the pancaspase inhibitor zVAD $(10 \mu \mathrm{M})$.

Cell shrinkage and cell membrane scrambling with phosphatidylserine translocation to the cell surface are both known to be stimulated by increase of cytosolic $\mathrm{Ca}^{2+}$ activity $\left(\left[\mathrm{Ca}^{2+}\right]_{i}\right)$. Thus, a further series of experiments was performed to elucidate the effect of Baicalein on $\left[\mathrm{Ca}^{2+}\right]_{i}$. Erythrocytes were loaded with Fluo3-AM and the Fluo3 fluorescence determined by flow cytometry following incubation for $48 \mathrm{~h}$ in Ringer solution without or with Baicalein $(5-50 \mu \mathrm{M})$. As illustrated in Figure 3, exposure of the erythrocytes to Baicalein increased the Fluo3 fluorescence, an effect reaching statistical significance at $50 \mu \mathrm{M}$ Baicalein concentration. 
Figure 2. Effect of Baicalein on phosphatidylserine exposure. (A) Original histogram of annexin-V-binding erythrocytes following exposure for $48 \mathrm{~h}$ to Ringer solution without (grey area) and with (black line) presence of $50 \mu \mathrm{M}$ Baicalein; (B) Arithmetic means \pm SEM of erythrocyte annexin-V-binding $(n=12)$ following incubation for $48 \mathrm{~h}$ to Ringer solution without (white bar) or with (black bars) presence of Baicalein $(5-50 \mu \mathrm{M}) . * * *(p<0.001)$ indicates significant difference from the absence of Baicalein (ANOVA). For comparison, the arithmetic means \pm SEM of hemolysis $(n=4)$ following incubation for $48 \mathrm{~h}$ to Ringer solution without or with presence of Baicalein is shown (grey bars); (C) Original dot blots of forward scatter as a function of annexin-V-binding following exposure for $48 \mathrm{~h}$ to Ringer solution without and with presence of $50 \mu \mathrm{M}$ Baicalein; (D) Arithmetic means \pm SEM $(n=5)$ of annexin-V-binding erythrocytes (arbitrary units) following exposure for 6-48 h to Ringer solution without (white squares) or with $50 \mu \mathrm{M}$ Baicalein (black squares). $* * *(p<0.001)$ indicates significant difference from the absence of Baicalein; (E) Confocal images of FITC dependent fluorescence (upper panels) and light microscopy (lower panels) of human erythrocytes stained with FITC-conjugated annexin-V following a $48 \mathrm{~h}$ exposure to Ringer without (left panels) or with (right panels) $50 \mu \mathrm{M}$ Baicalein; (F) Arithmetic means $\pm \operatorname{SEM}(n=5)$ of the percentage of annexin-V-binding erythrocytes after a $48 \mathrm{~h}$ treatment with Ringer solution without (white bars) or with $50 \mu \mathrm{M}$ Baicalein (black bars) in the absence (left panels) and presence (right panels) of $10 \mu \mathrm{M}$ pancaspase inhibitor $\mathrm{zVAD}$. $* * *(p<0.001)$ indicates significant difference from the absence of Baicalein (ANOVA).
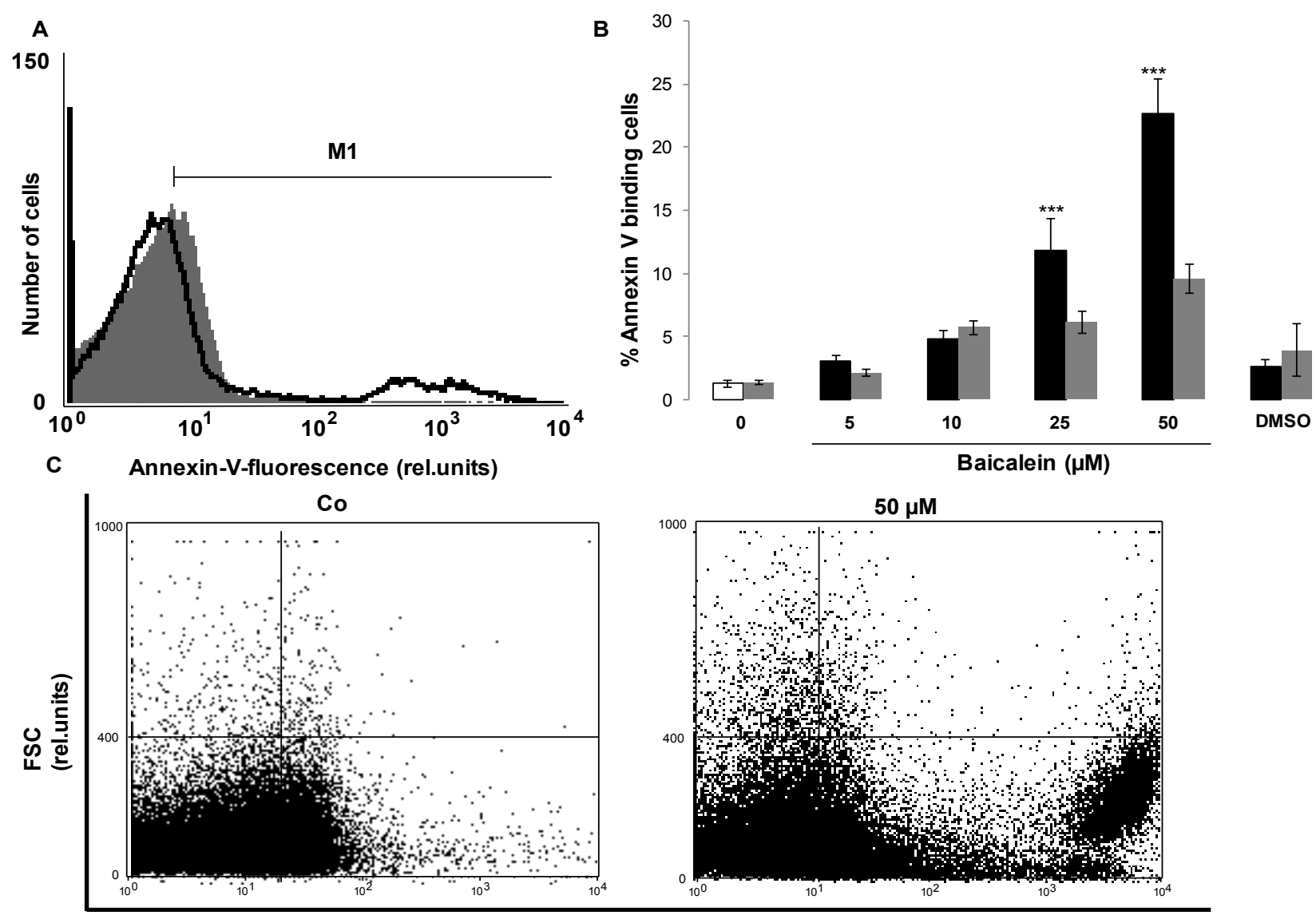

Annexin-V-fluorescence (rel.units) 
Figure 2. Cont.

D
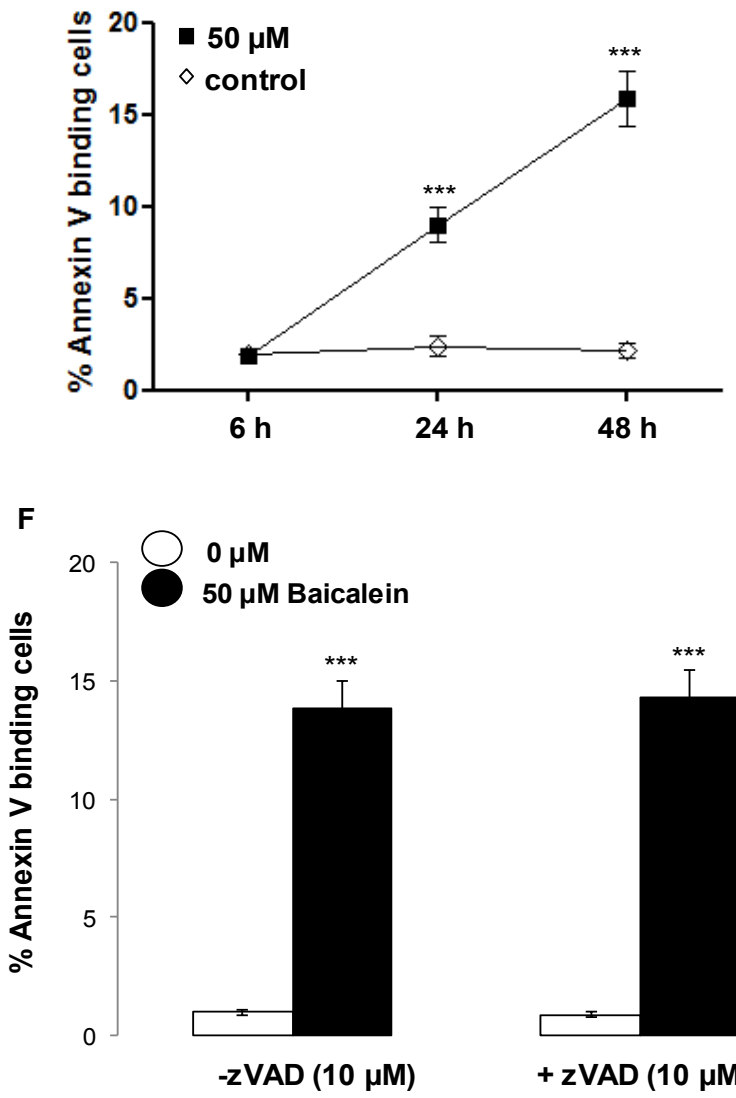

E
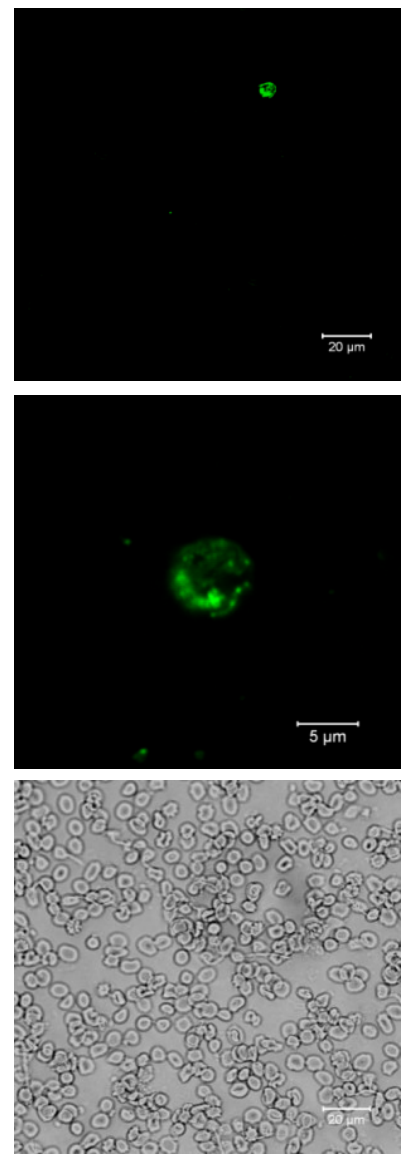

Control
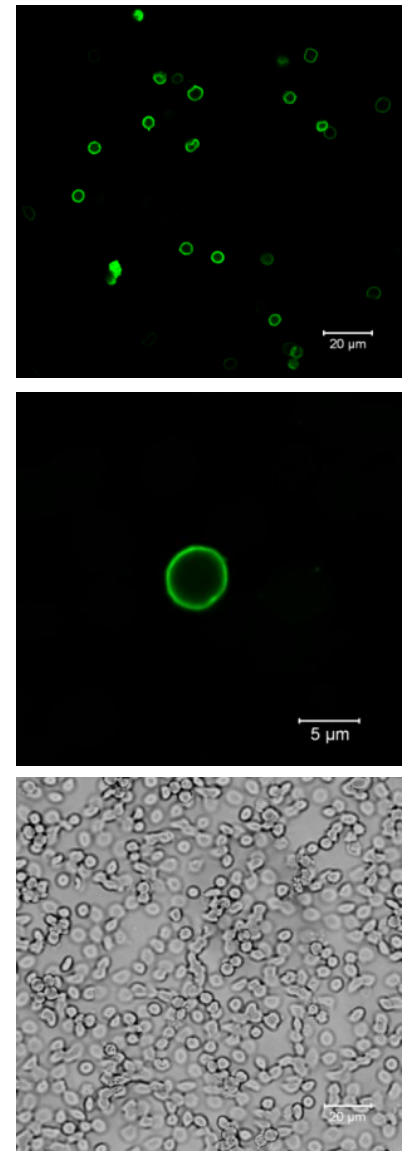

$50 \mu \mathrm{M}$ Baicalein

Figure 3. Effect of Baicalein on erythrocyte cytosolic $\mathrm{Ca}^{2+}$ concentration. (A) Original histogram of Fluo3 fluorescence in erythrocytes following exposure for $48 \mathrm{~h}$ to Ringer solution without (grey area) and with (black line) presence of $50 \mu \mathrm{M}$ Baicalein; (B) Arithmetic means $\pm \operatorname{SEM}(n=12)$ of the Fluo3 fluorescence (arbitrary units) in erythrocytes exposed for $48 \mathrm{~h}$ to Ringer solution without (white bar) or with (black bars) Baicalein $(5-50 \mu \mathrm{M})$. $* *(p<0.01)$ indicates significant difference from the absence of Baicalein (ANOVA); (C) Arithmetic means $\pm \operatorname{SEM}(n=5)$ of Fluo 3 fluorescence (arbitrary units) in erythrocytes exposed for $6-48 \mathrm{~h}$ to Ringer solution without (white squares) or with $50 \mu \mathrm{M}$ Baicalein (black squares). * $(p<0.05)$ indicates significant difference from the absence of Baicalein.

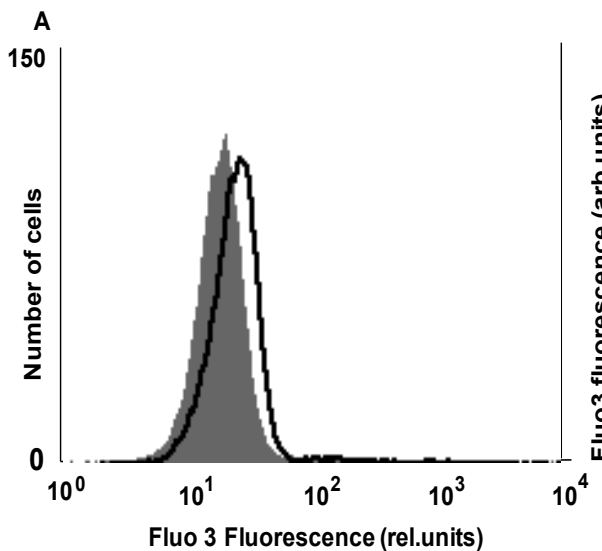

B

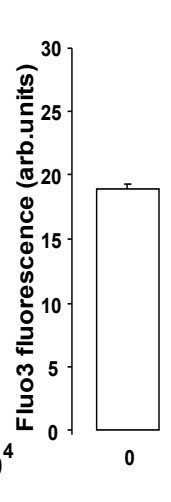

0

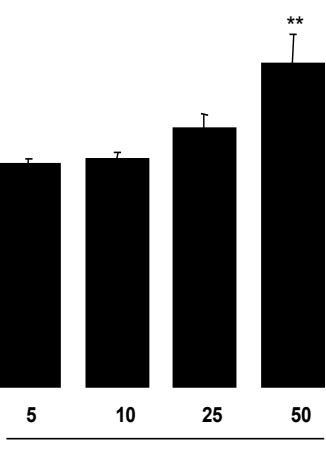

Baicalein $(\mu \mathrm{M})$
C

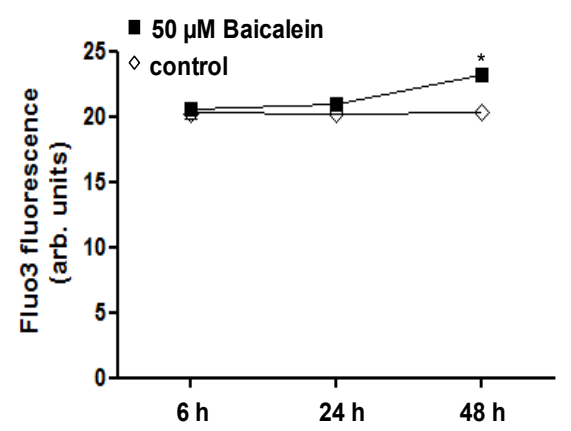


Exposure of the erythrocytes to the $\mathrm{Ca}^{2+}$ ionophore ionomycin was followed by a strong increase of annexin-V-binding (Figure 4). In order to test, whether the Baicalein-induced cell membrane scrambling required entry of extracellular $\mathrm{Ca}^{2+}$, erythrocytes were exposed for $48 \mathrm{~h}$ to $50 \mu \mathrm{M}$ Baicalein in the presence or nominal absence of extracellular $\mathrm{Ca}^{2+}$. As illustrated in Figure 4, the effect of Baicalein on annexin-V-binding was significantly blunted in the nominal absence of $\mathrm{Ca}^{2+}$. Nevertheless, even in the nominal absence of extracellular $\mathrm{Ca}^{2+}$, the percentage of annexin-V-binding erythrocytes was significantly higher in the presence than in the absence of Baicalein. Thus, Baicalein was effective partially, but not exclusively, through stimulation of $\mathrm{Ca}^{2+}$ entry.

Figure 4. (A) Effect of ionomycin on phosphatidylserine exposure. Arithmetic means \pm SEM $(n=5)$ of the percentage of annexin-V-binding erythrocytes following incubation for $1 \mathrm{~h}$ in the absence (white bar) or presence (black bar) of $1 \mu \mathrm{M}$ ionomycin. $* * *(p<0.001)$ indicates significant difference from the absence of $1 \mu \mathrm{M}$ ionomycin (ANOVA); (B) Effect of $\mathrm{Ca}^{2+}$ withdrawal on Baicalein- induced annexin-V-binding. Arithmetic means $\pm \operatorname{SEM}(n=5)$ of the percentage of annexin-V-binding erythrocytes after a $48 \mathrm{~h}$ treatment with Ringer solution without (white bars) or with (black bars) $50 \mu \mathrm{M}$ Baicalein in the presence (left bars, +Calcium) and absence (right bars, - Calcium) of calcium. $* * *(p<0.001)$ indicates significant difference from the respective values in the absence of Baicalein, \#\#\# ( $p<0.001)$ indicates significant difference from the respective value in the presence of $\mathrm{Ca}^{2+}(\mathrm{ANOVA})$.

A

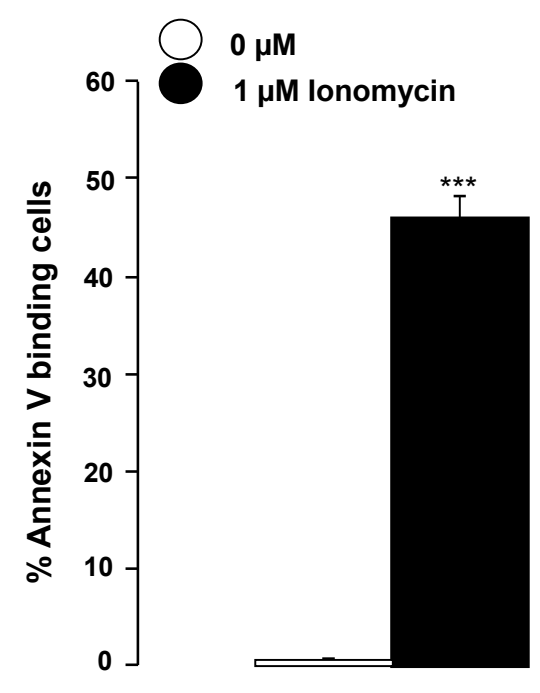

B

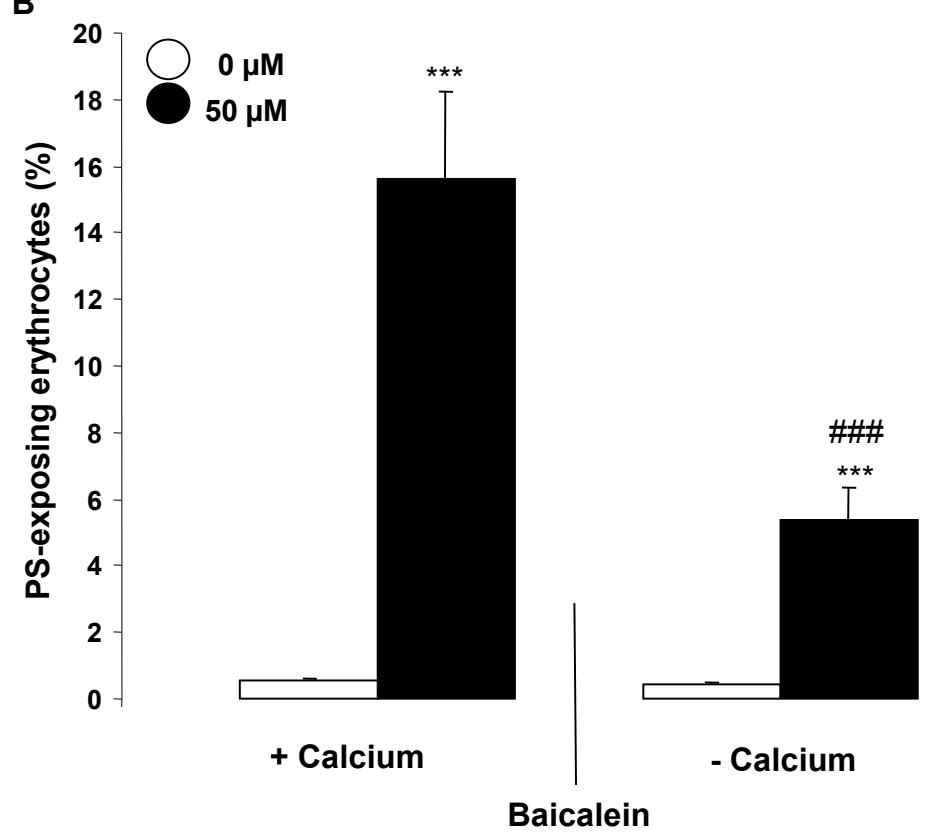

In search for an additional mechanism triggering eryptosis following Baicalein treatment, further experiments were performed to possibly disclose an effect of Baicalein on ceramide formation. Ceramide abundance at the erythrocyte surface was quantified utilizing an anti-ceramide antibody. As illustrated in Figure 5, exposure of erythrocytes to $50 \mu \mathrm{M}$ Baicalein significantly increased the ceramide abundance at the erythrocyte surface. 
Figure 5. Effect of Baicalein on ceramide formation. (A) Original histogram of ceramide surface abundance of erythrocytes following exposure for $48 \mathrm{~h}$ to Ringer solution without (grey shadow) and with (black line) presence of $50 \mu \mathrm{M}$ Baicalein; (B) Arithmetic means \pm SEM $(n=5)$ of ceramide abundance after a $48 \mathrm{~h}$ incubation in Ringer solution without (white bar) or with $50 \mu \mathrm{M}$ Baicalein (black bar). ${ }^{*}(p<0.05)$ indicates significant difference from the absence of Baicalein ( $t$-test); (C) Original dot blots of forward scatter as a function of ceramide abundance following exposure for $48 \mathrm{~h}$ to Ringer solution without and with the presence of $50 \mu \mathrm{M}$ Baicalein.

A

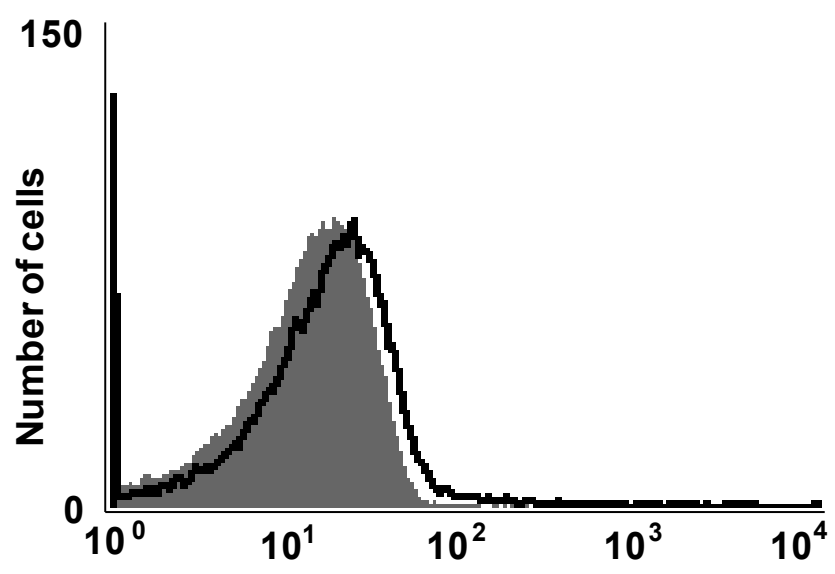

B

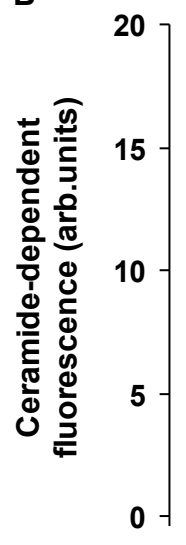

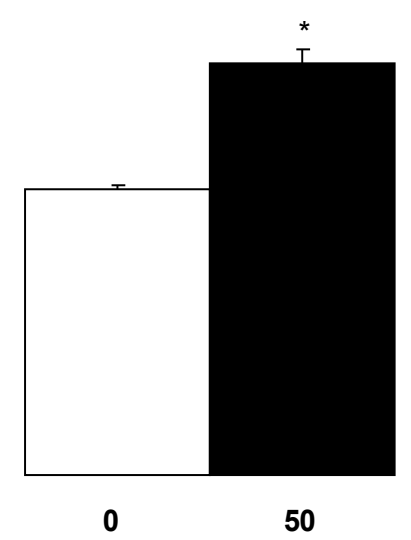

Baicalein $(\mu \mathrm{M})$
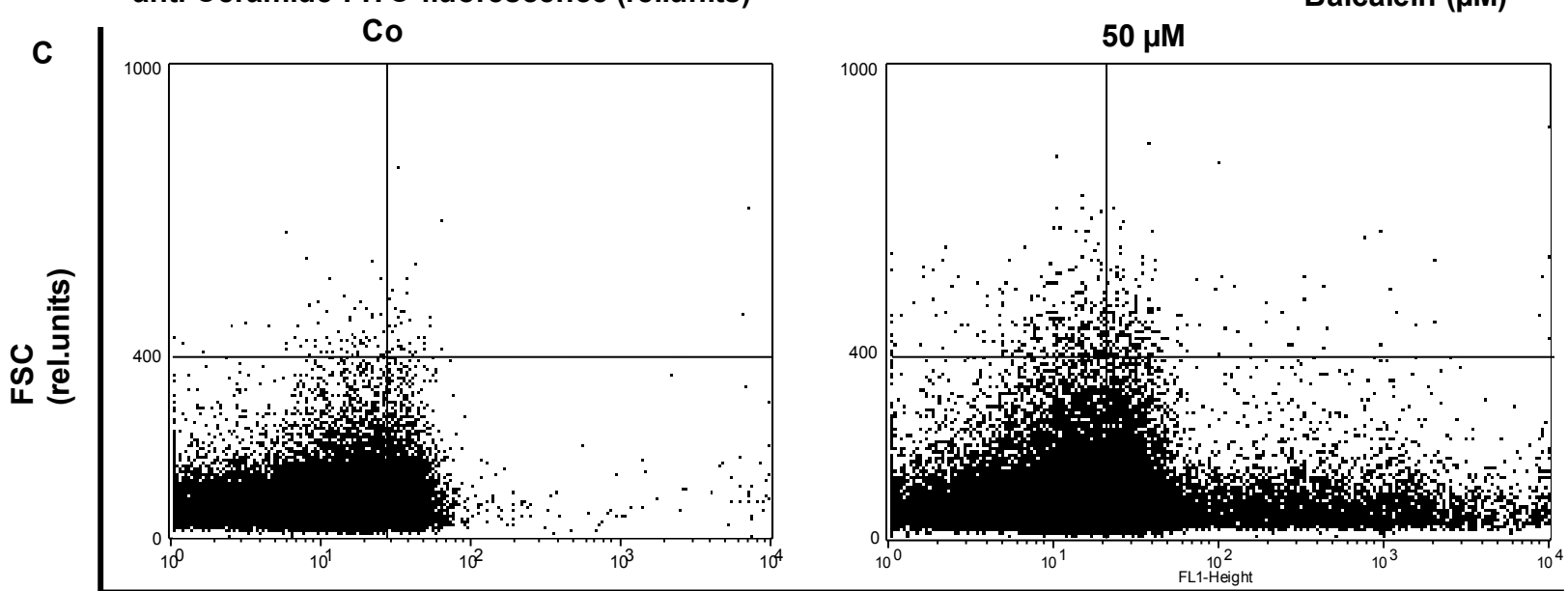

Ceramide abundance (rel.units)

The present study discloses a novel effect of Baicalein, i.e., stimulation of eryptosis, the suicidal death of erythrocytes. Incubation of human erythrocytes with Baicalein is followed by cell membrane scrambling with phosphatidylserine translocation to the erythrocyte surface, the most important hallmark of eryptosis. The Baicalein induced cell membrane scrambling affected only a subpopulation of the erythrocytes, an observation pointing to variable vulnerability of the erythrocytes. According to an earlier study, the susceptibility against several triggers of eryptosis is enhanced in aged erythrocytes [44].

On average, Baicalein further decreases cell volume, another hallmark of eryptosis. However, Baicalein exposure increases cell volume of an erythrocyte subpopulation. This observation again points to heterogeneity among the erythrocytes, which may be similarly due to differences in 
erythrocyte age. The Baicalein concentrations $(10-25 \mu \mathrm{M})$ required for those effects were in the range of the peak concentrations reported in Baicalein treated rats [70]. However, Baicalein was not immediately effective but a $24 \mathrm{~h}$ exposure of erythrocytes to the substance was required in order to trigger eryptosis. Whether or not those high concentrations could be maintained in vivo for $24 \mathrm{~h}$ remains uncertain.

Baicalein increased cytosolic $\mathrm{Ca}^{2+}$ activity $\left(\left[\mathrm{Ca}^{2+}\right]_{i}\right)$, an effect presumably due to stimulation of cation channels in the cell membrane. Earlier studies revealed that the erythrocyte cation channels involve TRPC6 [22].

The cell shrinkage following Baicalein treatment was presumably the result of $\mathrm{Ca}^{2+}$ entry with subsequent increase of $\left[\mathrm{Ca}^{2+}\right]_{i}$, activation of $\mathrm{Ca}^{2+}$ sensitive $\mathrm{K}^{+}$channels, $\mathrm{K}^{+}$exit, cell membrane hyperpolarisation, $\mathrm{Cl}^{-}$exit and thus cellular loss of $\mathrm{KCl}$ accompanied by osmotically driven water [23]. The cellular loss of $\mathrm{KCl}$ with water serves to counteract the swelling and subsequent hemolysis of injured erythrocytes. Hemolysis leads to release of hemoglobin, which is subject to glomerular filtration with subsequent precipitation in the acidic lumen of renal tubules [71]. The swelling of some erythrocytes following Baicalein exposure may result from $\mathrm{Na}^{+}$entry through the unselective cation channel.

The stimulation of cell membrane scrambling by Baicalein is similarly in part due to increase of $\left[\mathrm{Ca}^{2+}\right]_{i}$. Accordingly, the effect of Baicalein on phosphatidylserine translocation is in part dependent on entry of extracellular $\mathrm{Ca}^{2+}$.

However, even in the absence of extracellular $\mathrm{Ca}^{2+}$, Baicalein treatment is still followed by a significant increase of phosphatidylserine exposure. The residual effect is in part due to stimulation of ceramide formation. Ceramide is a well-known stimulator of eryptosis [22].

Similar to what has been shown for several other stimulators of eryptosis [22], the effect of Baicalein was not sensitive to the pancaspase inhibitor zVAD and thus did not require activation of caspases.

Consequences of excessive eryptosis include anemia, since phosphatidylserine exposing eryptotic erythrocytes are phagocytosed and thus rapidly cleared from circulating blood [22]. Anemia is prevented as long as accelerated clearance of erythrocytes during stimulated eryptosis is compensated by a similarly accelerated formation of new erythrocytes [22].

At least in theory, phosphatidylserine exposing erythrocytes may further interfere with microcirculation [72-77], as phosphatidylserine exposing erythrocytes adhere to endothelial CXCL16/SR-PSO [73], stimulate blood clotting and trigger thrombosis [72,78,79]. Baicalein has, however, been shown to counteract thrombosis and to inhibit thrombin-induced production of plasminogen activator inhibitor-1, and endothelial adhesion molecule expression [1]. Accordingly, Baicalein and its analogs have been proposed for the treatment of arteriosclerosis and hypertension [1].

Elimination of phosphatidylserine exposing erythrocytes may protect against untoward effects of hemolysis [22]. The removal of phosphatidylserine exposing erythrocytes further impacts on the clinical course of malaria [80]. Infected erythrocytes undergo eryptosis [80], since the intraerythrocytic pathogen activates ion channels including the $\mathrm{Ca}^{2+}$-permeable erythrocyte cation channels $[81,82]$. Subsequent clearance of phosphatidylserine exposing infected erythrocytes from circulating blood decreases parasitemia and by the same token precedes and thus prevents hemolysis of the parasitized erythrocytes [80]. Accordingly, the clinical course of malaria is ameliorated by genetic disorders sensitizing erythrocytes to eryptosis, such as sickle-cell trait, beta-thalassemia-trait, homozygous $\mathrm{Hb}-\mathrm{C}$ 
and G6PD-deficiency, [22,83-85], by conditions with enhanced eryptosis, such as iron deficiency [86], and by eryptosis stimulating xenobiotics, such as lead [87], chlorpromazine [88] or NO synthase inhibitors [89]. In theory, Baicalein may similarly decrease parasitemia in malaria.

\section{Experimental Section}

\subsection{Erythrocytes, Solutions and Chemicals}

Leukocyte-depleted erythrocytes were kindly provided by the blood bank of the University of Tübingen. The study is approved by the ethics committee of the University of Tübingen (184/2003V). Erythrocytes were incubated in vitro at a hematocrit of $0.4 \%$ in Ringer solution containing (in $\mathrm{mM}$ ) $125 \mathrm{NaCl}, 5 \mathrm{KCl}, 1 \mathrm{MgSO}_{4}, 32 \mathrm{~N}$-2-hydroxyethylpiperazine- $N$-2-ethanesulfonic acid (HEPES), 5 glucose, $1 \mathrm{CaCl}_{2} ; \mathrm{pH} 7.4$ at $37^{\circ} \mathrm{C}$ for $48 \mathrm{~h}$. Where indicated, erythrocytes were exposed to Baicalein (Enzo Life Sciences, Lörrach, Germany) at the indicated concentrations. In $\mathrm{Ca}^{2+}$-free Ringer solution, $1 \mathrm{mM} \mathrm{CaCl}_{2}$ was substituted by $1 \mathrm{mM}$ glycol-bis(2-aminoethylether)- $N, N, N^{\prime}, N^{\prime}$-tetraacetic acid (EGTA).

\subsection{Analysis of Annexin-V-Binding and Forward Scatter}

After incubation under the respective experimental condition, $50 \mu \mathrm{L}$ cell suspension was washed in Ringer solution containing $5 \mathrm{mM} \mathrm{CaCl} 2$ and then stained with Annexin-V-FITC (1:200 dilution; ImmunoTools, Friesoythe, Germany) in this solution at $37{ }^{\circ} \mathrm{C}$ for 20 min under protection from light. In the following, the forward scatter (FSC) of the cells was determined, and annexin-V fluorescence intensity was measured with an excitation wavelength of $488 \mathrm{~nm}$ and an emission wavelength of $530 \mathrm{~nm}$ on a FACS Calibur (BD, Heidelberg, Germany).

\subsection{Measurement of Intracellular $\mathrm{Ca}^{2+}$}

After incubation, erythrocytes were washed in Ringer solution and then loaded with Fluo-3/AM (Biotium, Hayward, CA, USA) in Ringer solution containing $5 \mathrm{mM} \mathrm{CaCl}_{2}$ and $5 \mu \mathrm{M}$ Fluo-3/AM. The cells were incubated at $37^{\circ} \mathrm{C}$ for $30 \mathrm{~min}$ and washed twice in Ringer solution containing $5 \mathrm{mM} \mathrm{CaCl}_{2}$. The Fluo-3/AM-loaded erythrocytes were resuspended in $200 \mu \mathrm{L}$ Ringer. Then, $\mathrm{Ca}^{2+}$-dependent fluorescence intensity was measured with an excitation wavelength of $488 \mathrm{~nm}$ and an emission wavelength of $530 \mathrm{~nm}$ on a FACS Calibur (BD, Heidelberg, Germany).

\subsection{Determination of Ceramide Formation}

For the determination of ceramide abundance, a monoclonal antibody-based assay was used. After incubation, cells were stained for $1 \mathrm{~h}$ at $37^{\circ} \mathrm{C}$ with $1 \mu \mathrm{g} / \mathrm{mL}$ anti ceramide antibody (clone MID 15B4, Alexis, Grünberg, Germany) in PBS containing 0.1\% bovine serum albumin (BSA) at a dilution of 1:5. The samples were washed twice with PBS-BSA. Subsequently, the cells were stained for 30 min with polyclonal fluorescein isothiocyanate (FITC) conjugated goat anti-mouse IgG and IgM specific antibody (Pharmingen, Hamburg, Germany) diluted 1:50 in PBS-BSA. Unbound secondary antibody was removed by repeated washing with PBS-BSA. The samples were then analyzed by flow cytometric analysis with an excitation wavelength of $488 \mathrm{~nm}$ and an emission wavelength of $530 \mathrm{~nm}$. 


\subsection{Statistics}

Data are expressed as arithmetic means \pm SEM. As indicated in the figure legends, statistical analysis was made using ANOVA with Tukey's test as post-test and $t$-test as appropriate. $n$ denotes the number of different erythrocyte specimens studied. Since different erythrocyte specimens used in distinct experiments are differently susceptible to triggers of eryptosis, the same erythrocyte specimens have been used for control and experimental conditions.

\section{Conclusions}

In conclusion, the polyphenolic flavonoid Baicalein stimulates $\mathrm{Ca}^{2+}$ entry and ceramide formation thus leading to subsequent erythrocyte shrinkage and erythrocyte cell membrane scrambling. Accordingly, Baicalein stimulates eryptosis, the suicidal erythrocyte death. The concentrations required for those effects are $10-50 \mu \mathrm{M}$.

\section{Acknowledgments}

The authors acknowledge the meticulous preparation of the manuscript by Tanja Loch. The study was supported by the Deutsche Forschungsgemeinschaft and the Open Access Publishing Fund of Tuebingen University.

\section{Author Contributions}

Rosi Bissinger, Abaid Malik, Sabina Honisch and Jamshed Warsi performed experiments and evaluated the data; Kashif Jilani designed the experiments; Florian Lang drafted the manuscript and all authors corrected and approved the manuscript.

\section{Conflicts of Interest}

The authors declare no conflict of interest.

\section{References}

1. Huang, Y.; Tsang, S.Y.; Yao, X.; Chen, Z.Y. Biological properties of baicalein in cardiovascular system. Curr. Drug Targets Cardiovasc. Haematol. Disord. 2005, 5, 177-184.

2. Donald, G.; Hertzer, K.; Eibl, G. Baicalein-An intriguing therapeutic phytochemical in pancreatic cancer. Curr. Drug Targets 2012, 13, 1772-1776.

3. Kim, S.J.; Kim, H.J.; Kim, H.R.; Lee, S.H.; Cho, S.D.; Choi, C.S.; Nam, J.S.; Jung, J.Y. Antitumor actions of baicalein and wogonin in HT-29 human colorectal cancer cells. Mol. Med. Rep. 2012, 6, 1443-1449.

4. Li, H.L.; Zhang, S.; Wang, Y.; Liang, R.R.; Li, J.; An, P.; Wang, Z.M.; Yang, J.; Li, Z.F. Baicalein induces apoptosis via a mitochondrial-dependent caspase activation pathway in T24 bladder cancer cells. Mol. Med. Rep. 2013, 7, 266-270.

5. Li-Weber, M. New therapeutic aspects of flavones: The anticancer properties of Scutellaria and its main active constituents Wogonin, Baicalein and Baicalin. Cancer Treat. Rev. 2009, 35, 57-68. 
6. Luo, R.; Wang, J.; Zhao, L.; Lu, N.; You, Q.; Guo, Q.; Li, Z. Synthesis and biological evaluation of baicalein derivatives as potent antitumor agents. Bioorg. Med. Chem. Lett. 2014, 24, 1334-1338.

7. Ma, G.Z.; Liu, C.H.; Wei, B.; Qiao, J.; Lu, T.; Wei, H.C.; Chen, H.D.; He, C.D. Baicalein inhibits DMBA/TPA-induced skin tumorigenesis in mice by modulating proliferation, apoptosis, and inflammation. Inflammation 2013, 36, 457-467.

8. Nipun Babu, V.; Kannan, S. Enhanced delivery of baicalein using cinnamaldehyde cross-linked chitosan nanoparticle inducing apoptosis. Int. J. Biol. Macromol. 2012, 51, 1103-1108.

9. Chen, Y.J.; Wu, C.S.; Shieh, J.J.; Wu, J.H.; Chen, H.Y.; Chung, T.W.; Chen, Y.K.; Lin, C.C. Baicalein Triggers Mitochondria-Mediated Apoptosis and Enhances the Antileukemic Effect of Vincristine in Childhood Acute Lymphoblastic Leukemia CCRF-CEM Cells. Evid. Based Complement. Altern. Med. 2013, 2013, 124747. doi:10.1155/2013/124747.

10. Helmerick, E.C.; Loftus, J.P.; Wakshlag, J.J. The effects of baicalein on canine osteosarcoma cell proliferation and death. Vet. Comp. Oncol. 2012, doi:10.1111/vco.12013.

11. Kim, D.H.; Hossain, M.A.; Kang, Y.J.; Jang, J.Y.; Lee, Y.J.; Im, E.; Yoon, J.H.; Kim, H.S.; Chung, H.Y.; Kim, N.D.; et al. Baicalein, an active component of Scutellaria baicalensis Georgi, induces apoptosis in human colon cancer cells and prevents AOM/DSS-induced colon cancer in mice. Int. J. Oncol. 2013, 43, 1652-1658.

12. Zhang, H.B.; Lu, P.; Guo, Q.Y.; Zhang, Z.H.; Meng, X.Y. Baicalein induces apoptosis in esophageal squamous cell carcinoma cells through modulation of the PI3K/Akt pathway. Oncol. Lett. 2013, 5, 722-728.

13. Zhang, Y.; Song, L.; Cai, L.; Wei, R.; Hu, H.; Jin, W. Effects of baicalein on apoptosis, cell cycle arrest, migration and invasion of osteosarcoma cells. Food Chem. Toxicol. 2013, 53, 325-333.

14. Dong, Q.H.; Zheng, S.; Xu, R.Z.; Lu, Q.H. Baicalein selectively induce apoptosis in human leukemia K562 cells. Yao Xиe Xие Bao 2003, 38, 817-820.

15. Chang, W.T.; Li, J.; Vanden Hoek, M.S.; Zhu, X.; Li, C.Q.; Huang, H.H.; Hsu, C.W.; Zhong, Q.; Li, J.; Chen, S.J.; et al. Baicalein preconditioning protects cardiomyocytes from ischemia-reperfusion injury via mitochondrial oxidant signaling. Am. J. Chin. Med. 2013, 41, 315-331.

16. Chao, H.M.; Chuang, M.J.; Liu, J.H.; Liu, X.Q.; Ho, L.K.; Pan, W.H.; Zhang, X.M.; Liu, C.M.; Tsai, S.K.; Kong, C.W.; et al. Baicalein protects against retinal ischemia by antioxidation, antiapoptosis, downregulation of HIF-1alpha, VEGF, and MMP-9 and upregulation of HO-1. J. Ocul. Pharmacol. Ther. 2013, 29, 539-549.

17. Jung, E.B.; Lee, C.S. Baicalein attenuates proteasome inhibition-induced apoptosis by suppressing the activation of the mitochondrial pathway and the caspase-8- and Bid-dependent pathways. Eur. J. Pharmacol. 2014, 730, 116-124.

18. Mabalirajan, U.; Ahmad, T.; Rehman, R.; Leishangthem, G.D.; Dinda, A.K.; Agrawal, A.; Ghosh, B.; Sharma, S.K. Baicalein reduces airway injury in allergen and IL-13 induced airway inflammation. PLoS One 2013, 8, e62916.

19. Chen, S.S.; Michael, A.; Butler-Manuel, S.A. Advances in the treatment of ovarian cancer: A potential role of antiinflammatory phytochemicals. Discov. Med. 2012, 13, 7-17.

20. Song, L.; Yang, H.; Wang, H.X.; Tian, C.; Liu, Y.; Zeng, X.J.; Gao, E.; Kang, Y.M.; Du, J.; Li, H.H.; et al. Inhibition of 12/15 lipoxygenase by baicalein reduces myocardial ischemia/reperfusion injury via modulation of multiple signaling pathways. Apoptosis 2014, 19, 567-580. 
21. Zhang, Z.; Cui, W.; Li, G.; Yuan, S.; Xu, D.; Hoi, M.P.; Lin, Z.; Dou, J.; Han, Y.; Lee, S.M.; et al. Baicalein protects against 6-OHDA-induced neurotoxicity through activation of Keap1/Nrf2/HO-1 and involving PKCalpha and PI3K/AKT signaling pathways. J. Agric. Food Chem. 2012, 60, 8171-8182.

22. Lang, E.; Qadri, S.M.; Lang, F. Killing me softly-Suicidal erythrocyte death. Int. J. Biochem. Cell Biol. 2012, 44, 1236-1243.

23. Lang, P.A.; Kaiser, S.; Myssina, S.; Wieder, T.; Lang, F.; Huber, S.M. Role of $\mathrm{Ca}^{2+}$-activated K channels in human erythrocyte apoptosis. Am. J. Physiol. Cell Physiol. 2003, 285, C1553-C1560.

24. Abed, M.; Towhid, S.T.; Mia, S.; Pakladok, T.; Alesutan, I.; Borst, O.; Gawaz, M.; Gulbins, E.; Lang, F. Sphingomyelinase-induced adhesion of eryptotic erythrocytes to endothelial cells. Am. J. Physiol. Cell Physiol. 2012, 303, C991-C999.

25. Bhavsar, S.K.; Bobbala, D.; Xuan, N.T.; Foller, M.; Lang, F. Stimulation of suicidal erythrocyte death by alpha-lipoic acid. Cell. Physiol. Biochem. 2010, 26, 859-868.

26. Foller, M.; Feil, S.; Ghoreschi, K.; Koka, S.; Gerling, A.; Thunemann, M.; Hofmann, F.; Schuler, B.; Vogel, J.; Pichler, B.; et al. Anemia and splenomegaly in cGKI-deficient mice. Proc. Natl. Acad. Sci. USA 2008, 105, 6771-6776.

27. Foller, M.; Mahmud, H.; Gu, S.; Wang, K.; Floride, E.; Kucherenko, Y.; Luik, S.; Laufer, S.; Lang, F. Participation of leukotriene $\mathrm{C}(4)$ in the regulation of suicidal erythrocyte death. J. Physiol. Pharmacol. 2009, 60, 135-143.

28. Lau, I.P.; Chen, H.; Wang, J.; Ong, H.C.; Leung, K.C.; Ho, H.P.; Kong, S.K. In vitro effect of CTAB- and PEG-coated gold nanorods on the induction of eryptosis/erythroptosis in human erythrocytes. Nanotoxicology 2012, 6, 847-856.

29. Maellaro, E.; Leoncini, S.; Moretti, D.; del Bello, B.; Tanganelli, I.; de Felice, C.; Ciccoli, L. Erythrocyte caspase-3 activation and oxidative imbalance in erythrocytes and in plasma of type 2 diabetic patients. Acta Diabetol. 2013, 50, 489-495.

30. Foller, M.; Sopjani, M.; Koka, S.; Gu, S.; Mahmud, H.; Wang, K.; Floride, E.; Schleicher, E.; Schulz, E.; Munzel, T.; et al. Regulation of erythrocyte survival by AMP-activated protein kinase. FASEB J. 2009, 23, 1072-1080.

31. Kucherenko, Y.; Zelenak, C.; Eberhard, M.; Qadri, S.M.; Lang, F. Effect of casein kinase 1alpha activator pyrvinium pamoate on erythrocyte ion channels. Cell. Physiol. Biochem. 2012, 30, 407-417.

32. Zelenak, C.; Eberhard, M.; Jilani, K.; Qadri, S.M.; Macek, B.; Lang, F. Protein kinase CK1alpha regulates erythrocyte survival. Cell. Physiol. Biochem. 2012, 29, 171-180.

33. Bhavsar, S.K.; Gu, S.; Bobbala, D.; Lang, F. Janus kinase 3 is expressed in erythrocytes, phosphorylated upon energy depletion and involved in the regulation of suicidal erythrocyte death. Cell. Physiol. Biochem. 2011, 27, 547-556.

34. Klarl, B.A.; Lang, P.A.; Kempe, D.S.; Niemoeller, O.M.; Akel, A.; Sobiesiak, M.; Eisele, K.; Podolski, M.; Huber, S.M.; Wieder, T.; et al. Protein kinase C mediates erythrocyte "programmed cell death" following glucose depletion. Am. J. Physiol. Cell Physiol. 2006, 290, C244-C253.

35. Gatidis, S.; Zelenak, C.; Fajol, A.; Lang, E.; Jilani, K.; Michael, D.; Qadri, S.M.; Lang, F. p38 MAPK activation and function following osmotic shock of erythrocytes. Cell. Physiol. Biochem. 2011, 28, 1279-1286. 
36. Zelenak, C.; Foller, M.; Velic, A.; Krug, K.; Qadri, S.M.; Viollet, B.; Lang, F.; Macek, B. Proteome analysis of erythrocytes lacking AMP-activated protein kinase reveals a role of PAK2 kinase in eryptosis. J. Proteome Res. 2011, 10, 1690-1697.

37. Lupescu, A.; Jilani, K.; Zelenak, C.; Zbidah, M.; Qadri, S.M.; Lang, F. Hexavalent chromium-induced erythrocyte membrane phospholipid asymmetry. Biometals 2012, 25, 309-318.

38. Shaik, N.; Lupescu, A.; Lang, F. Sunitinib-sensitive suicidal erythrocyte death. Cell. Physiol. Biochem. 2012, 30, 512-522.

39. Abed, M.; Towhid, S.T.; Shaik, N.; Lang, F. Stimulation of suicidal death of erythrocytes by rifampicin. Toxicology 2012, 302, 123-128.

40. Bottger, E.; Multhoff, G.; Kun, J.F.; Esen, M. Plasmodium falciparum-infected erythrocytes induce granzyme B by NK cells through expression of host-Hsp70. PLoS One 2012, 7, e33774.

41. Firat, U.; Kaya, S.; Cim, A.; Buyukbayram, H.; Gokalp, O.; Dal, M.S.; Tamer, M.N. Increased caspase-3 immunoreactivity of erythrocytes in STZ diabetic rats. Exp. Diabetes Res. 2012, 2012, 316384. doi:10.1155/2012/316384.

42. Ganesan, S.; Chaurasiya, N.D.; Sahu, R.; Walker, L.A.; Tekwani, B.L. Understanding the mechanisms for metabolism-linked hemolytic toxicity of primaquine against glucose 6-phosphate dehydrogenase deficient human erythrocytes: Evaluation of eryptotic pathway. Toxicology 2012, 294, 54-60.

43. Gao, M.; Cheung, K.L.; Lau, I.P.; Yu, W.S.; Fung, K.P.; Yu, B.; Loo, J.F.; Kong, S.K. Polyphyllin D induces apoptosis in human erythrocytes through $\mathrm{Ca}^{2+}$ rise and membrane permeabilization. Arch. Toxicol. 2012, 86, 741-752.

44. Ghashghaeinia, M.; Cluitmans, J.C.; Akel, A.; Dreischer, P.; Toulany, M.; Koberle, M.; Skabytska, Y.; Saki, M.; Biedermann, T.; Duszenko, M.; et al. The impact of erythrocyte age on eryptosis. Br. J. Haematol. 2012, 157, 606-614.

45. Jilani, K.; Lupescu, A.; Zbidah, M.; Abed, M.; Shaik, N.; Lang, F. Enhanced Apoptotic Death of Erythrocytes Induced by the Mycotoxin Ochratoxin A. Kidney Blood Press. Res. 2012, 36, 107-118.

46. Jilani, K.; Qadri, S.M.; Lang, F. Geldanamycin-induced phosphatidylserine translocation in the erythrocyte membrane. Cell. Physiol. Biochem. 2013, 32, 1600-1609.

47. Kucherenko, Y.V.; Lang, F. Inhibitory Effect of Furosemide on Non-Selective Voltage-Independent Cation Channels in Human Erythrocytes. Cell. Physiol. Biochem. 2012, 30, 863-875.

48. Lupescu, A.; Jilani, K.; Zbidah, M.; Lang, E.; Lang, F. Enhanced $\mathrm{Ca}^{2+}$ entry, ceramide formation, and apoptotic death of erythrocytes triggered by plumbagin. J. Nat. Prod. 2012, 75, 1956-1961.

49. Lupescu, A.; Jilani, K.; Zbidah, M.; Lang, F. Induction of apoptotic erythrocyte death by rotenone. Toxicology 2012, 300, 132-137.

50. Polak-Jonkisz, D.; Purzyc, L. Ca Influx versus efflux during eryptosis in uremic erythrocytes. Blood Purif. 2012, 34, 209-210.

51. Qian, E.W.; Ge, D.T.; Kong, S.K. Salidroside protects human erythrocytes against hydrogen peroxide-induced apoptosis. J. Nat. Prod. 2012, 75, 531-537.

52. Shaik, N.; Zbidah, M.; Lang, F. Inhibition of $\mathrm{Ca}^{2+}$ entry and suicidal erythrocyte death by naringin. Cell. Physiol. Biochem. 2012, 30, 678-686.

53. Vota, D.M.; Maltaneri, R.E.; Wenker, S.D.; Nesse, A.B.; Vittori, D.C. Differential erythropoietin action upon cells induced to eryptosis by different agents. Cell Biochem. Biophys. 2013, 65, 145-157. 
54. Weiss, E.; Cytlak, U.M.; Rees, D.C.; Osei, A.; Gibson, J.S. Deoxygenation-induced and $\mathrm{Ca}^{2+}$ dependent phosphatidylserine externalisation in red blood cells from normal individuals and sickle cell patients. Cell Calcium 2012, 51, 51-56.

55. Zappulla, D. Environmental stress, erythrocyte dysfunctions, inflammation, and the metabolic syndrome: Adaptations to $\mathrm{CO}_{2}$ increases? J. Cardiometab. Syndr. 2008, 3, 30-34.

56. Zbidah, M.; Lupescu, A.; Jilani, K.; Lang, F. Stimulation of suicidal erythrocyte death by fumagillin. Basic Clin. Pharmacol. Toxicol. 2013, 112, 346-351.

57. Zbidah, M.; Lupescu, A.; Shaik, N.; Lang, F. Gossypol-induced suicidal erythrocyte death. Toxicology 2012, 302, 101-105.

58. Zelenak, C.; Pasham, V.; Jilani, K.; Tripodi, P.M.; Rosaclerio, L.; Pathare, G.; Lupescu, A.; Faggio, C.; Qadri, S.M.; Lang, F.; et al. Tanshinone IIA stimulates erythrocyte phosphatidylserine exposure. Cell. Physiol. Biochem. 2012, 30, 282-294.

59. Abed, M.; Herrmann, T.; Alzoubi, K.; Pakladok, T.; Lang, F. Tannic Acid induced suicidal erythrocyte death. Cell. Physiol. Biochem. 2013, 32, 1106-1116.

60. Ahmed, M.S.; Langer, H.; Abed, M.; Voelk1, J.; Lang, F. The uremic toxin acrolein promotes suicidal erythrocyte death. Kidney Blood Press. Res. 2013, 37, 158-167.

61. Ghashghaeinia, M.; Cluitmans, J.C.; Toulany, M.; Saki, M.; Koberle, M.; Lang, E.; Dreischer, P.; Biedermann, T.; Duszenko, M.; Lang, F.; et al. Age Sensitivity of NFкB Abundance and Programmed Cell Death in Erythrocytes Induced by NFкB Inhibitors. Cell. Physiol. Biochem. 2013, 32, 801-813.

62. Abed, M.; Feger, M.; Alzoubi, K.; Pakladok, T.; Frauenfeld, L.; Geiger, C.; Towhid, S.T.; Lang, F. Sensitization of erythrocytes to suicidal erythrocyte death following water deprivation. Kidney Blood Press. Res. 2013, 37, 567-578.

63. Alzoubi, K.; Honisch, S.; Abed, M.; Lang, F. Triggering of Suicidal Erythrocyte Death by Penta- $O$-galloyl- $\beta$-D-glucose. Toxins 2014, 6, 54-65.

64. Jilani, K.; Lang, F. Carmustine-induced phosphatidylserine translocation in the erythrocyte membrane. Toxins 2013, 5, 703-716.

65. Jilani, K.; Enkel, S.; Bissinger, R.; Almilaji, A.; Abed, M.; Lang, F. Fluoxetine induced suicidal erythrocyte death. Toxins 2013, 5, 1230-1243.

66. Lupescu, A.; Bissinger, R.; Jilani, K.; Lang, F. Triggering of suicidal erythrocyte death by celecoxib. Toxins 2013, 5, 1543-1554.

67. Lupescu, A.; Jilani, K.; Zbidah, M.; Lang, F. Patulin-induced suicidal erythrocyte death. Cell. Physiol. Biochem. 2013, 32, 291-299.

68. Lang, E.; Qadri, S.M.; Jilani, K.; Zelenak, C.; Lupescu, A.; Schleicher, E.; Lang, F. Carbon monoxide-sensitive apoptotic death of erythrocytes. Basic Clin. Pharmacol. Toxicol. 2012, 111, 348-355.

69. Voelkl, J.; Alzoubi, K.; Mamar, A.K.; Ahmed, M.S.; Abed, M.; Lang, F. Stimulation of Suicidal Erythrocyte Death by Increased Extracellular Phosphate Concentrations. Kidney Blood Press. Res. 2014, 38, 42-51.

70. Wakui, Y.; Yanagisawa, E.; Ishibashi, E.; Matsuzaki, Y.; Takeda, S.; Sasaki, H.; Aburada, M.; Oyama, T. Determination of baicalin and baicalein in rat plasma by high-performance liquid chromatography with electrochemical detection. J. Chromatogr. 1992, 575, 131-136. 
71. Harrison, H.E.; Bunting, H.; Ordway, N.K.; Albrink, W.S. The Pathogenesis of the Renal Injury Produced in the Dog by Hemoglobin or Methemoglobin. J. Exp. Med. 1947, 86, 339-356.

72. Andrews, D.A.; Low, P.S. Role of red blood cells in thrombosis. Curr. Opin. Hematol. 1999, 6, 76-82.

73. Borst, O.; Abed, M.; Alesutan, I.; Towhid, S.T.; Qadri, S.M.; Foller, M.; Gawaz, M.; Lang, F. Dynamic adhesion of eryptotic erythrocytes to endothelial cells via CXCL16/SR-PSOX. Am. J. Physiol. Cell Physiol. 2012, 302, C644-C651.

74. Closse, C.; Dachary-Prigent, J.; Boisseau, M.R. Phosphatidylserine-related adhesion of human erythrocytes to vascular endothelium. Br. J. Haematol. 1999, 107, 300-302.

75. Gallagher, P.G.; Chang, S.H.; Rettig, M.P.; Neely, J.E.; Hillery, C.A.; Smith, B.D.; Low, P.S. Altered erythrocyte endothelial adherence and membrane phospholipid asymmetry in hereditary hydrocytosis. Blood 2003, 101, 4625-4627.

76. Pandolfi, A.; di Pietro, N.; Sirolli, V.; Giardinelli, A.; di Silvestre, S.; Amoroso, L.; di Tomo, P.; Capani, F.; Consoli, A.; Bonomini, M.; et al. Mechanisms of uremic erythrocyte-induced adhesion of human monocytes to cultured endothelial cells. J. Cell. Physiol. 2007, 213, 699-709.

77. Wood, B.L.; Gibson, D.F.; Tait, J.F. Increased erythrocyte phosphatidylserine exposure in sickle cell disease: Flow-cytometric measurement and clinical associations. Blood 1996, 88, 1873-1880.

78. Chung, S.M.; Bae, O.N.; Lim, K.M.; Noh, J.Y.; Lee, M.Y.; Jung, Y.S.; Chung, J.H. Lysophosphatidic acid induces thrombogenic activity through phosphatidylserine exposure and procoagulant microvesicle generation in human erythrocytes. Arterioscler. Thromb. Vasc. Biol. 2007, 27, 414-421.

79. Zwaal, R.F.; Comfurius, P.; Bevers, E.M. Surface exposure of phosphatidylserine in pathological cells. Cell. Mol. Life Sci. 2005, 62, 971-988.

80. Foller, M.; Bobbala, D.; Koka, S.; Huber, S.M.; Gulbins, E.; Lang, F. Suicide for survival—Death of infected erythrocytes as a host mechanism to survive malaria. Cell. Physiol. Biochem. 2009, 24, 133-140.

81. Duranton, C.; Huber, S.; Tanneur, V.; Lang, K.; Brand, V.; Sandu, C.; Lang, F. Electrophysiological properties of the Plasmodium falciparum-induced cation conductance of human erythrocytes. Cell. Physiol. Biochem. 2003, 13, 189-198.

82. Kirk, K. Membrane transport in the malaria-infected erythrocyte. Physiol. Rev. 2001, 81, 495-537.

83. Ayi, K.; Giribaldi, G.; Skorokhod, A.; Schwarzer, E.; Prendergast, P.T.; Arese, P. 16alpha-bromoepiandrosterone, an antimalarial analogue of the hormone dehydroepiandrosterone, enhances phagocytosis of ring stage parasitized erythrocytes: A novel mechanism for antimalarial activity. Antimicrob. Agents Chemother. 2002, 46, 3180-3184.

84. Ayi, K.; Turrini, F.; Piga, A.; Arese, P. Enhanced phagocytosis of ring-parasitized mutant erythrocytes: A common mechanism that may explain protection against falciparum malaria in sickle trait and beta-thalassemia trait. Blood 2004, 104, 3364-3371.

85. Cappadoro, M.; Giribaldi, G.; O’Brien, E.; Turrini, F.; Mannu, F.; Ulliers, D.; Simula, G.; Luzzatto, L.; Arese, P. Early phagocytosis of glucose-6-phosphate dehydrogenase (G6PD)-deficient erythrocytes parasitized by Plasmodium falciparum may explain malaria protection in G6PD deficiency. Blood 1998, 92, 2527-2534. 
86. Koka, S.; Foller, M.; Lamprecht, G.; Boini, K.M.; Lang, C.; Huber, S.M.; Lang, F. Iron deficiency influences the course of malaria in Plasmodium berghei infected mice. Biochem. Biophys. Res. Commun. 2007, 357, 608-614.

87. Koka, S.; Huber, S.M.; Boini, K.M.; Lang, C.; Foller, M.; Lang, F. Lead decreases parasitemia and enhances survival of Plasmodium berghei-infected mice. Biochem. Biophys. Res. Commun. 2007, 363, 484-489.

88. Koka, S.; Lang, C.; Boini, K.M.; Bobbala, D.; Huber, S.M.; Lang, F. Influence of chlorpromazine on eryptosis, parasitemia and survival of Plasmodium berghe infected mice. Cell. Physiol. Biochem. 2008, 22, 261-268.

89. Koka, S.; Lang, C.; Niemoeller, O.M.; Boini, K.M.; Nicolay, J.P.; Huber, S.M.; Lang, F. Influence of NO synthase inhibitor L-NAME on parasitemia and survival of Plasmodium berghei infected mice. Cell. Physiol. Biochem. 2008, 21, 481-488.

(C) 2014 by the authors; licensee MDPI, Basel, Switzerland. This article is an open access article distributed under the terms and conditions of the Creative Commons Attribution license (http://creativecommons.org/licenses/by/3.0/). 